Article

\title{
In Vitro and Clinical Safety Assessment of the Multiple W/O/W Emulsion Based on the Active Ingredients from Rosmarinus officinalis L., Avena sativa L. and Linum usitatissimum L.
}

\author{
Ugne Zlabiene $^{1}\left(\mathbb{D}\right.$, Juste Baranauskaite ${ }^{2}$, Dalia M. Kopustinskiene ${ }^{1}$ (D) and Jurga Bernatoniene ${ }^{1,3, *(D)}$ \\ 1 Institute of Pharmaceutical Technology, Faculty of Pharmacy, Medical Academy, Lithuanian University of \\ Health Sciences, Sukileliu pr. 13, LT-50161 Kaunas, Lithuania; ugne.cizauskaite@lsmuni.lt (U.Z.); \\ DaliaMarija.Kopustinskiene@lsmuni.lt (D.M.K.) \\ 2 Department of Analytical and Toxicological Chemistry, Faculty of Pharmacy, Medical Academy, Lithuanian \\ University of Health Sciences, Sukileliu pr. 13, LT-50161 Kaunas, Lithuania; juste.baranauskaite@lsmuni.lt \\ 3 Department of Drug Technology and Social Pharmacy, Faculty of Pharmacy, Medical Academy, Lithuanian \\ University of Health Sciences, Sukileliu pr. 13, LT-50161 Kaunas, Lithuania \\ * Correspondence: jurga.bernatoniene@1smuni.lt; Tel.: +370-600-63349
}

Citation: Zlabiene, U.;

Baranauskaite, J.; Kopustinskiene,

D.M.; Bernatoniene, J. In Vitro and

Clinical Safety Assessment of the

Multiple W/O/W Emulsion Based on

the Active Ingredients from

Rosmarinus officinalis L., Avena sativa L.

and Linum usitatissimum

L. Pharmaceutics 2021, 13, 732

https://doi.org/10.3390/

pharmaceutics 13050732

Academic Editors: Rolf Daniels,

Dominique Lunter and M.

Begoña Delgado-Charro

Received: 13 April 2021

Accepted: 13 May 2021

Published: 16 May 2021

Publisher's Note: MDPI stays neutral with regard to jurisdictional claims in published maps and institutional affiliations.

Copyright: (C) 2021 by the authors. Licensee MDPI, Basel, Switzerland. This article is an open access article distributed under the terms and conditions of the Creative Commons Attribution (CC BY) license (https:/ / creativecommons.org/licenses/by/ $4.0 /)$.
Abstract: The multiple W/O/W emulsion supplemented with the extracts of Rosmarinus officinalis L., Avena sativa L. and Linum usitatissimum L. was prepared in the study, its active compounds were determined by HPLC and its safety was evaluated in vitro by the means of reconstituted human skin model EpiDerm ${ }^{\mathrm{TM}}$ for the assessment of its irritation, phototoxicity and early skin inflammation effects and by the $48 \mathrm{~h}$ human skin patch test for its skin irritation and allergenic potential. The microbiological challenge test of $\mathrm{W} / \mathrm{O} / \mathrm{W}$ emulsion was performed to ensure its preservation efficiency. The results showed that the $\mathrm{W} / \mathrm{O} / \mathrm{W}$ emulsion loaded with self-preserving plant-based bio-actives had no irritant potential, was not phototoxic and did not provoke skin inflammation or sensitization and thus could be used as a safe base for cosmetic products. Furthermore, our results demonstrate that the safety evaluation of cosmetic ingredients of natural or organic origin could be easily performed using reconstructed human skin model EpiDerm ${ }^{\mathrm{TM}}$ similar to the well-defined chemicals used in the cosmetics industry.

Keywords: multiple emulsion; microbiological challenge test; EpiDerm ${ }^{\mathrm{TM}}$; patch test; skin irritation; phototoxicity

\section{Introduction}

In recent years, plant-derived substances have been widely investigated not only as bioactive ingredients, but also as the additives in the production of the semi-solid pharmaceuticals and cosmetics to enhance their moisturizing properties, decrease oxidative and inflammatory processes in the skin and to improve their characteristics as surfactants or viscosity modifiers [1]. Their versatile properties determine the variety of possible applications they could be used in ecological cosmetics, though their technological impact has been often overlooked. Water-in oil-in water $(\mathrm{W} / \mathrm{O} / \mathrm{W})$ multiple emulsions are composed of small aqueous phase droplets which are trapped inside larger oil droplets dispersed in a continuous phase. These complex emulsions have been in the focus of attention as innovative vehicles for the drug delivery, especially in cosmetics and pharmaceutical products due to the various functional properties such as masking of odor and taste, protection against oxidation to prolong the shelf-life of bioactives. Multiple emulsions also have potential as micro carriers of the lipophilic and hydrophilic ingredients entrapped in the inner phase, which can be subsequently released [2,3]. Generally, W/O/W or O/W/O are prepared by a two stage or one stage emulsification process, thought the loss of the internal phase during the inversion or shear stress and the complexity of the techniques are the major issues [2,4] Recently, we designed the novel water-in oil-in water (W/O/W) multiple 
emulsion which was formed directly by using Rosmarinus officinalis L. extract and it was stabilized with natural structuring agents like Avena sativa L. and Linum usitatissimum L. improving its rheological properties and skin characteristics $[5,6]$.

However, the plant-based bioactive compounds may pose the risk of skin sensitization and allergic reactions [7] and therefore, the safety of natural components in cosmetic and pharmaceutical products should be carefully evaluated to prevent the aggravation of existing skin conditions during their application [1]. It has been reported that ingredients of natural origin such as argan oil, wolf's bane, lavender, peppermint and some essential oils may cause contact dermatitis and urticaria [8-10]. However, these ingredients are widely used in cosmetics and pharmaceutical preparations and the evidence of their safety is underreported. The protein-containing crops, loaded in the $\mathrm{W} / \mathrm{O} / \mathrm{W}$ emulsion, also may induce an allergic reaction [11,12]. Therefore, the toxicological assessment of topically applied products containing known sensitizing agents should be mandatory.

The EU Regulation (EC) N $N^{\circ} 1223 / 2009$ foresees that the safety assessment of the finished product must be performed before it can be placed on the EU market, moreover, the testing of the finished cosmetic products and cosmetic ingredients on animals is prohibited [13]. Previously, the potential of a compound or the preparation to cause the skin irritation or corrosion has been evaluated using a rabbit skin test [14]. The public organizations and relevant institutions are requiring minimization of the in vivo skin corrosion testing on animals due to the pain and trauma it causes to the test subjects [15]. An alternative strategy to the animal test was the use of human volunteers to identify skin irritation hazard $[16,17]$. To comply with these requirements, we have used alternative toxicological assays in this study. Recently, the reconstituted 3D human skin models were validated to identify the chemical sensitization in vitro [13].They are applicable to cosmetic, pharmaceutical and medical device safety testing [18]. In comparison to the epidermis models or the single-layer cell cultures, the 3D models have better performance in the efficacy testing due to the similarity to human skin especially the interaction between the dermis and epidermis. It serves as a more acceptable instrument for the formulation chemists, because not only a single chemical ingredient but also their composition can be tested. The repeated application process and the long term incubation can be performed as well, which is extremely important in the safety assessment of the products [19]. However, despite the wide acceptance of these models for the regulatory purposes, they are rarely used to test cosmetic products containing natural ingredients. There is an increasing evidence that plant-derived materials safely used many years for food or medicine production might cause allergic reactions and increase health risks to the consumers when used in the cosmetic industry $[20,21]$. Nevertheless, a thorough safety assessment and clinical scientific data of botanicals in cosmetics is often overlooked [21]. Therefore, this study is one of the first attempts to evaluate the microbiological and toxicological safety of the innovative selfpreserving multiple emulsion with natural ingredients. A microbiological challenge test was used to evaluate preservation efficiency of the $\mathrm{W} / \mathrm{O} / \mathrm{W}$ emulsion and reconstituted human skin model EpiDerm ${ }^{\mathrm{TM}}[13,22]$ - to evaluate its irritation [22], phototoxicity [23] and early skin inflammation effects. The skin sensitization of the multiple emulsion was assessed based on the $48 \mathrm{~h}$ human skin patch test [24].

\section{Materials and Methods}

\subsection{Materials}

Dried rosemary (Rosmarinus officinalis L.) leaves and flaxseed (Linum usitatissimum Linn.) were purchased from UAB "Sirdazole", Lithuania. The oat groats (Avena sativa L.) used for the preparation of colloidal oatmeal were obtained from UAB "Skaneja", Lithuania. The viscosity modifier ViscOptima ${ }^{\mathrm{TM}}$ SE (Croda, East Yorkshire, UK), consisting of Sodium Polyacrylate, Ethylhexyl Cocoate, PPG-3 Benzyl Ether Myristate and Polysorbate 20, was used as an emulsifying agent. Extra-virgin olive oil was purchased from UAB "Anira", Lithuania. Ethanol (96\%) was purchased from UAB "Stumbras" (Kaunas, Lithuania). Distilled water was used throughout the experiment. 
The EpiDerm ${ }^{\mathrm{TM}}$ (EPI-200) skin inserts, the three-dimensional reconstructed human skin model consisting of normal human-derived keratinocytes, multiple viable cell layers and functional stratum corneum and MTT Kit (MTT-100) to test cell viability were from MatTek In Vitro Life Science Laboratories Corporation (Bratislava, Slovakia). The Quantikine ${ }^{\circledR}$ Human IL-1 $\alpha /$ IL-1F1 immunoassay was from R\&D Systems (Minneapolis, MN, USA).

\subsection{Preparation of Plant Extracts}

Dried rosemary leave extract was prepared by the ultrasound assisted extraction (Bandelin electronic $\mathrm{GmbH} \&$ Co.KG, Berlin, Germany) using ethanol (90\%) as the solvent. The solvent to material ratio was $1: 15$, the extraction temperature was $60^{\circ} \mathrm{C}$; the extraction time was $10 \mathrm{~min}$. The HPLC analysis showed that the extract contained $0.58 \mathrm{mg} / \mathrm{mL}$ rosmarinic acid, $1.06 \mathrm{mg} / \mathrm{mL}$ ursolic acid and $0.62 \mathrm{mg} / \mathrm{mL}$ oleanolic acid [5].

Colloidal oatmeal was prepared by the extraction of oats carried out by using magnetic stirrer (MSH-20A, Witeg Labotechnik $\mathrm{GmbH}$, Wertheim, Germany). Whole oat groats were extracted in $250 \mathrm{~mL}$ flask for $1 \mathrm{~h}$ at $98 \pm 2{ }^{\circ} \mathrm{C}$ temperature, using distilled water as the extraction solvent. Solvent to material ratio was 1:20. The hot extract was filtered through four layers of cheesecloth and was allowed to cool to room temperature. According to the TLC analysis it contained $\beta$-glucan $(0.44 \pm 0.02 \%), \mathrm{L}-(+)$-arabinose $(340.44 \pm 0.01 \mathrm{mg} / \mathrm{g}$ dried preparation), D-(+)-xylose (12.64 $\pm 0.01 \mathrm{mg} / \mathrm{g}$ dried preparation), D-(+)-galacturonic acid (34.21 $\pm 0.04 \mathrm{mg} / \mathrm{g}$ dried preparation) [5].

The flaxseed mucilage extraction was performed with boiling water at 1:20 ratio for 60 min using magnetic stirrer (MSH-20A, Witeg Labotechnik GmbH, Wertheim, Germany). The hot mixture was immediately filtered through the cotton based cheesecloth and left to cool down to the room temperature. The mucilage was examined by TLC [5]. It contained 1-L-rhamnose monohydrate (11.01 $\pm 0.01 \mathrm{mg} / \mathrm{g}$ dried extract), L-(+)-arabinose (165.72 \pm $0.01 \mathrm{mg} / \mathrm{g}$ dried extract), D-(+)-galactose (50.72 $\pm 0.01 \mathrm{mg} / \mathrm{g}$ dried extract), D-(+)-xylose $(297.76 \pm 0.01 \mathrm{mg} / \mathrm{g}$ dried extract), D-(+)-galacturonic acid $(21.46 \pm 0.04 \mathrm{mg} / \mathrm{g}$ dried extract).

The conditions of the HPLC and TLC are published in the previous studies [5,25].

\subsection{Preparation of the $W / O / W$ Emulsion}

The optimal composition of the $\mathrm{W} / \mathrm{O} / \mathrm{W}$ emulsion was determined in our previous study using the experimental mixture design matrix (Design Expert 9.0.4.01, Stat- Easy Inc., Minneapolis, MN, USA) [26]. Briefly, $0.5 \%$ of emulsifier ViscOptima ${ }^{\mathrm{TM}}$ SE was mixed into the olive oil (20\%), followed by the addition of continuous phase containing water (3.79\%), rosemary extract $(7.5 \%)$, flaxseed mucilage $(24.18 \%)$ and colloidal oatmeal $(44.03 \%)$. The optimal technological parameters were previously determined, so the emulsion was stirred with mechanical stirrer IKA Eurostar 200 digital $\left(\right.$ IKA $^{\circledR}$-Werke GmbH \& Co. KG, Staufen, Germany) at a speed of $800 \mathrm{rpm}$ for $15 \mathrm{~min}$ [5]. The emulsion was stable as determined by 28 days short term stability assay and accelerated stability assay (at $38 \pm 2{ }^{\circ} \mathrm{C}$ and $75 \pm 5 \%$ relative humidity) $[5,27,28]$.

\subsection{Microbiological Challenge Testing}

The experiment was carried out according to the ISO 11930:2012 at room temperature $\left(20 \pm 3^{\circ} \mathrm{C}\right)$. The test strains were Aspergillus brasiliensis (ATCC 16404), Candida albicans (ATCC 10231), Escherichia coli (ATCC 8739), Staphylococcus aureus (ATCC 6538) and Pseudomonas aeruginosa (ATCC 9027). The culture media was tryptic soy agar (TSA) for bacteria, sabourad dextrose agar medium (SDA) for $C$. albicans and potato dextrose agar (PDA) for A. brasiliensis. The incubation temperature of Petri dishes was $32.5 \pm 2.5^{\circ} \mathrm{C}$ for $48-72 \mathrm{~h}$ for bacteria and C. albicans and $22.5 \pm 2.5^{\circ} \mathrm{C}$ for $3-5$ days for A. brasiliensis. For each stain $20 \mathrm{~g}$ of cream sample was used. $0.2 \mathrm{~mL}$ of calibrated inoculum was added. $1.0 \times 10^{5} \div 1.0 \times$ $10^{6} \mathrm{cfu} / \mathrm{mL}$ for bacteria and $1.0 \times 10^{4} \div 1.0 \times 10^{5} \mathrm{cfu} / \mathrm{mL}$ for fungi (Table 1 ). The samples 
were successfully neutralized with LT 100 liquid broth and the growth of the bacteria was observed after 7, 14 and 28 days.

Table 1. Demonstration of the neutralizer efficacy.

\begin{tabular}{ccccccc}
\hline Microorganisms & $\begin{array}{c}\mathbf{N}, \\
\mathbf{c f u} / \mathbf{m L}\end{array}$ & $\begin{array}{c}\mathbf{N}_{\mathbf{0}} \mathbf{c f u} \\
\mathbf{c f} / \mathbf{m L}\end{array}$ & $\begin{array}{c}\mathbf{N v f} \\
\mathbf{c f u} / \mathbf{m L}\end{array}$ & $\begin{array}{c}\mathbf{N v n} \\
\mathbf{c f u} / \mathbf{m L}\end{array}$ & $\begin{array}{c}\mathbf{N v f} \geq \mathbf{0 . 5} \\
\mathbf{N v n}\end{array}$ & $\begin{array}{c}\mathbf{N v}, \\
\mathbf{c f u} / \mathbf{m L}\end{array}$ \\
\hline $\begin{array}{c}\text { Escherichia coli } \\
\text { Staphylococcus aureus }\end{array}$ & $3.2 \times 10^{7}$ & $3.2 \times 10^{5}$ & $2.5 \times 10^{2}$ & $2.6 \times 10^{2}$ & $>0.5$ & $3.0 \times 10^{2}$ \\
Pseudomonas aeruginosa & $2.9 \times 10^{7}$ & $2.9 \times 10^{5}$ & $2.0 \times 10^{2}$ & $2.1 \times 10^{2}$ & $>0.5$ & $2.9 \times 10^{2}$ \\
Candida albicans & $1.4 \times 10^{7}$ & $3.7 \times 10^{5}$ & $1.2 \times 10^{2}$ & $1.4 \times 10^{2}$ & $>0.5$ & $1.2 \times 10^{2}$ \\
Aspergillus brasiliensis & $1.0 \times 10^{6}$ & $1.4 \times 10^{4}$ & $1.1 \times 10^{2}$ & $9.5 \times 10^{1}$ & $>0.5$ & $1.0 \times 10^{2}$ \\
\hline
\end{tabular}

$\mathrm{N}$-quantity of the initial numbers of microorganisms; $\mathrm{N}_{0}-\mathrm{N} / 100 ; \mathrm{Nvf}-$ number of microorganisms present in the test mixture with the neutralizer and formulation; Nvn-number of microorganisms present in the test mixture with the neutralizer in the absence of formulation; Nv-inoculum control.

\subsection{In Vitro Skin Irritation Test}

The validated ET-50 protocol provided by the supplier and was used for the in vitro skin irritation test. The EpiDerm ${ }^{\mathrm{TM}}$ skin inserts were transferred to 6-well plates containing 0.9 mL Dulbecco's Modified Eagle's Medium (DMEM) per well and pre-incubated in the humidified $37^{\circ} \mathrm{C}, 5 \% \mathrm{CO}_{2}$ incubator overnight. Before the test, the assay medium was replaced by the fresh medium and $100 \mu \mathrm{L}$ of test sample was applied topically on the EpiDerm ${ }^{\mathrm{TM}}$ skin inserts and the samples were incubated for 3, 5 and $18 \mathrm{~h}$. 1\% Triton X-100 was used as positive control while distilled water as a negative control. Three replicates of EpiDerm ${ }^{\mathrm{TM}}$ skin inserts were used for each experiment.

At the end of each exposure time, the assay media from the 6-well plates were collected and used further for the IL- $1 \alpha$ assay. The EpiDerm ${ }^{\mathrm{TM}}$ skin inserts were rinsed with PBS twice and transferred to 3-(4,5-Dimethylthiazol-2-yl)-2,5-diphenyltetrazolium bromide (MTT; $300 \mu \mathrm{L}$ of a $0.3 \mathrm{mg} / \mathrm{mL}$ solution) containing 24-well plate for the cell viability testing. For the MTT test, the samples were kept in a $5 \% \mathrm{CO}_{2}$ environment for $3 \mathrm{~h} .2 \mathrm{~mL}$ of isopropanol was used to extract formazan. The optical density (OD) of $200 \mu \mathrm{L}$ of the isopropanol extract was measured at $570 \mathrm{~nm}$ using a UV-Vis Spectrophotometer. The test material was considered to be irritant to skin if the tissue viability after exposure was $\leq$ $50 \%$.

\subsection{In Vitro Skin Phototoxicity Test}

The pre-validated phototoxicity protocol was provided by the supplier and was used for the in vitro skin phototoxicity test. The EpiDerm ${ }^{\mathrm{TM}}$ skin inserts were treated initially as in the skin irritation assay. For the exposure, 5 concentrations of the test material (dissolved in water) were topically applied onto 2 tissues per concentration, water was used as negative control. The second 12 tissue set was treated similarly. After the incubation of $18 \mathrm{~h}$ the half of the tissue samples were exposed to $1.7 \mathrm{~mW} / \mathrm{cm}^{2} \mathrm{UVA}$ and the others were kept in the dark for the same amount of time. Further on, they were washed with PBS, transferred to the fresh medium and incubated for $18 \mathrm{~h}$. Then, the assay medium was replaced by the MTT-medium and the samples were incubated for $3 \mathrm{~h}$. Finally, PBS was used to wash the inserts, the formazan was extracted with isopropanol. The OD was measured by the plate spectrophotometer at $570 \mathrm{~nm}$ and the cell viability was expressed as $\%$ of the corresponding negative control (irradiated or non-irradiated). For the positive control, the parallel experiment with the known phototoxic agent $-0.1 \%$ chlorpromazine solution (diluted to 5 concentrations) was performed.

\subsection{IL-1 $\alpha$ Assay for SKIN inflammation Testing}

The IL- $1 \alpha$ content was assessed using the Quantikine ${ }^{\circledR}$ Human IL- $1 \alpha /$ IL-1F1 immunoassay kit according to the DLA-50 protocol given by the manufacturer. $200 \mu \mathrm{L}$ of the tissue media collected after 3,5 and $18 \mathrm{~h}$ exposure during the in vitro skin irritation test as well as the positive (1\% Triton X-100) and the negative controls (distilled water) and $50 \mu \mathrm{L}$ of assay diluent were added to the antibody-precoated microplate wells and 
incubated for $2 \mathrm{~h}$ at the room temperature. Afterwards the streptavidin-horse radish peroxidase-conjugated secondary antibodies were added to the pre-washed test samples and the plate was incubated for $60 \mathrm{~min}$ at $22 \pm 2{ }^{\circ} \mathrm{C}$. Then, the substrate solution was added and the plate was incubated again for $20 \mathrm{~min}$. The chemical reaction was stopped by adding $50 \mu \mathrm{L}$ of $2 \mathrm{~N}$ sulfuric acid. The OD was measured by the microplate reader at $450 \mathrm{~nm}$ with a correction wavelength of $570 \mathrm{~nm}$. The standard curve was used to calculate the concentration $(\mathrm{R}=0.99864)$. IL- $1 \alpha$ concentration higher than $85 \mathrm{pg} / \mathrm{mL}$ was considered a marker of inflammation.

\subsection{Hours Human Skin Patch Test}

The study was carried out at the clinic of general and aesthetic dermatology "Clinic In" (Vilnius, Lithuania). The test methods and the selection procedure of human volunteer were executed according to the Declaration of Helsinki and International Ethical Guidelines for Biomedical Research Involving Human Subjects [29].

A total of 18 healthy volunteers (6 men and 12 women) above 18 years old were selected. They have signed informed consent form before the beginning of the study. The age of participants varied between 24 and 71 years $(\mathrm{M}=44.7$ years). The selected criteria for inclusion were: healthy upper back skin with the absence of dermatological conditions, inflammation or dryness which resulted in desquamation; no participation in other medical studies; no known allergies and no application of topical drugs or the use of oral drugs that may affect skin reactions. The exclusion criteria were: an active skin and other uncontrollable disease, the use of medicine that might provoke skin reactions, pregnancy and breastfeeding, the age younger than 18 years old, Lithuanian language knowledge not sufficient to understand the information provided. The investigation was carried out according to the COLIPA recommendations and the Regulation (EC) No 1223/2009 of the European Parliament and of the Council of 30 November 2009 on cosmetic products [13].

The participants $12 \mathrm{~h}$ before and during the study could not use any skin care products. $20 \mathrm{mg}$ of test material was applied to the Finn chamber (Epitest Ltd. Oy., Tuusula, Finland) on Scanpor tape (Alpharma AS, Norway). The Finn chamber size was $11.0 \mathrm{~mm}$ and the size of the aluminum cup was $8.0 \mathrm{~mm}$. On the upper back of volunteers, the chamber strips were placed and sealed for $48 \mathrm{~h}$ using surgical tape in order to prevent peeling of adjacent skin and avoid the unnecessary movement of the chambers containing test sample (Mepore, Molnlycke Health Care, Gothenburg, Sweden). The skin around it was marked with a waterproof marker. Participants were assessed by dermatologist and allergologist after 48, 72, $96 \mathrm{~h}$ and 7 days according to the criteria set out by the International Contact Dermatitis Research Group [30,31].

\subsection{Statistical Analysis}

The results are given as mean \pm SD. One-way and two-way ANOVA with Dunnett's post hoc test was used to carry out the statistical analysis (Prism v. 5.04, GraphPad Software Inc., La Jolla, CA, USA). The level of significance of $95 \%$ was chosen for the study.

\section{Results and Discussion}

Topically applied products are subject to a range of testing to protect users from microbiological and chemical contamination and from other possible toxic effects. Usually, eco-friendly or natural ingredients-based products are more susceptible to microbiological contamination and they have shorter shelf life unless heavily preserved. However, some natural ingredients possess antimicrobial properties and their incorporation in the formulation helps to decrease the amount of chemical preservatives or even replace them completely [32,33].

Since the composition of created innovative multiple emulsion is natural-based and preservative free and according to the microbiological quality assay carried out in our previous study the CFU complies with the requirements of European Pharmacopoeia 7.0 01/2011:50104, the possible microbial contamination during the usage period must be 
still considered before the in vivo and in vitro evaluation to avoid the possible negative reactions. To assess the robustness of the products against microbial contamination, the challenge test according to the ISO 11930:2012 was carried out. The W/O/W emulsion contains rosemary extract which is widely used in the cosmetics and food industry due to the antimicrobial properties [34-36]. Moreno et al. have determined that main active compounds responsible for inhibiting bacterial growth are phenolic acids: rosmarinic and carnosic acids [37]. Therefore, the rosmarinic acid was identified in the extract which was used in the formulation of the self-preserving multiple emulsion based on the hypothesis that the preservation efficiency of the product is in line with the requirements of Regulation (EC) No 1223/2009. The obtained data confirmed the hypothesis that the $\mathrm{W} / \mathrm{O} / \mathrm{W}$ emulsion is efficiently preserved using herbal extracts (Table 2). The growth of the bacteria and fungi was not observed after 7, 14 and 28 days. Based on the literature and our experimental data it could be concluded that rosemary extract and/or its essential oils are suitable as an alternative to chemical preservatives for the topical semi-solid preparations [35,38]. The microbiological quality of the multiple emulsion complies with the requirements of the regulatory documents and the multiple emulsion is safe to use in further in vitro and in vivo studies.

Table 2. Results of a microbiological challenge testing (efficacy of the antimicrobial protection).

\begin{tabular}{ccccccc}
\hline \multirow{2}{*}{ Microorganisms } & \multicolumn{6}{c}{$\log$ Reduction Values $\left(\mathbf{R}_{\mathbf{x}}=\lg \mathbf{N}_{\mathbf{0}}-\lg \mathbf{N}_{\mathbf{x}}\right)$} \\
\cline { 2 - 7 } & T7 & Criteria & T14 & Criteria & T28 & Criteria \\
\hline Escherichia coli & 4.5 & $\geq 3$ & 4.5 & $\geq 3$ and NI & 4.5 & $\geq 3$ and NI \\
Staphylococcus aureus & 4.5 & $\geq 3$ & 4.5 & $\geq 3$ and NI & 4.5 & $\geq 3$ and NI \\
Pseudomonas aeruginosa & 4.6 & $\geq 3$ & 4.6 & $\geq 3$ and NI & 4.6 & $\geq 3$ and NI \\
Candida albicans & 3.1 & $\geq 1$ & 3.1 & $\geq 1$ and NI & 3.1 & $\geq 1$ and NI \\
Aspergillus brasiliensis & 3.0 & - & 3.0 & $\geq 0$ & 3.0 & $\geq 0$ \\
\hline
\end{tabular}

$\mathrm{N}_{0}$-number of microorganisms inoculated at time $\mathrm{t}_{0} ; \mathrm{N}_{\mathrm{x}}$-number of surviving microorganisms at each sampling time $t_{x}(\mathrm{~T} 7, \mathrm{~T} 14, \mathrm{~T} 28)$; NI-no increase in the count from the previous contact time T7, T14, T28 days.

To proceed further with the development of the emulsion-based cosmetic product containing herbal extracts we assessed its safety using the reconstituted 3D human skin models as an alternative to the in vivo animal testing. First, the skin irritation potential was evaluated. It was determined that the $0.1 \%$ triton X-100 solution (positive control) has a significant impact on the cell viability: after $3 \mathrm{~h}$ it decreased by $23.51 \pm 4.68 \%$, after $5 \mathrm{~h}$ $28.83 \pm 5.08 \%$ and after $18 \mathrm{~h} 93.41 \pm 0.68 \%$ (Figure 1 ).

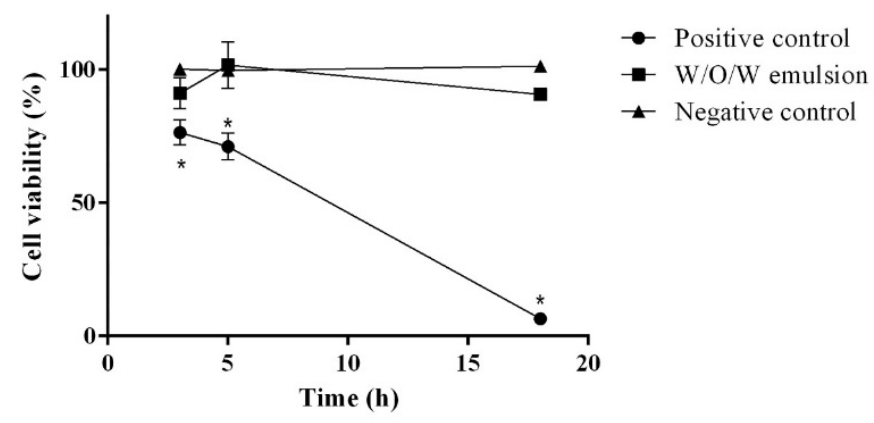

Figure 1. The influence of $\mathrm{W} / \mathrm{O} / \mathrm{W}$ emulsion on the cell viability during in vitro skin irritation test. $\mathrm{N}=4 * p<0.05$ vs. negative control and $\mathrm{W} / \mathrm{O} / \mathrm{W}$ emulsion.

The concentration of ethanolic rosemary extract in the composition of $\mathrm{W} / \mathrm{O} / \mathrm{W}$ emulsion was $7.5 \%$. According to the Food and Drug Administration (USA) the recommended concentration of the rosemary extract in the topical products should be $0.001-10 \%$, as these concentrations did not result in skin irritation [39]. These data comply with the results of our study: the application of the $\mathrm{W} / \mathrm{O} / \mathrm{W}$ emulsion did not change the cell viability which varied between $90.74 \%$ and $101.71 \%(p>0.05)$. The influence of the presence of ethanol in the topically applied products on the skin erythema was widely investigated in various 
scientific studies, thus, in our results it is worth mentioning that there was no statistically significant difference in the cell viability between the negative control (distilled water) and multiple emulsion, which contains ethanol (Figure 2). The obtained results corresponded with the data obtained by the recent studies that ethanol-based products were well tolerated by the skin and could decrease the skin moisture only insignificantly $[40,41]$.

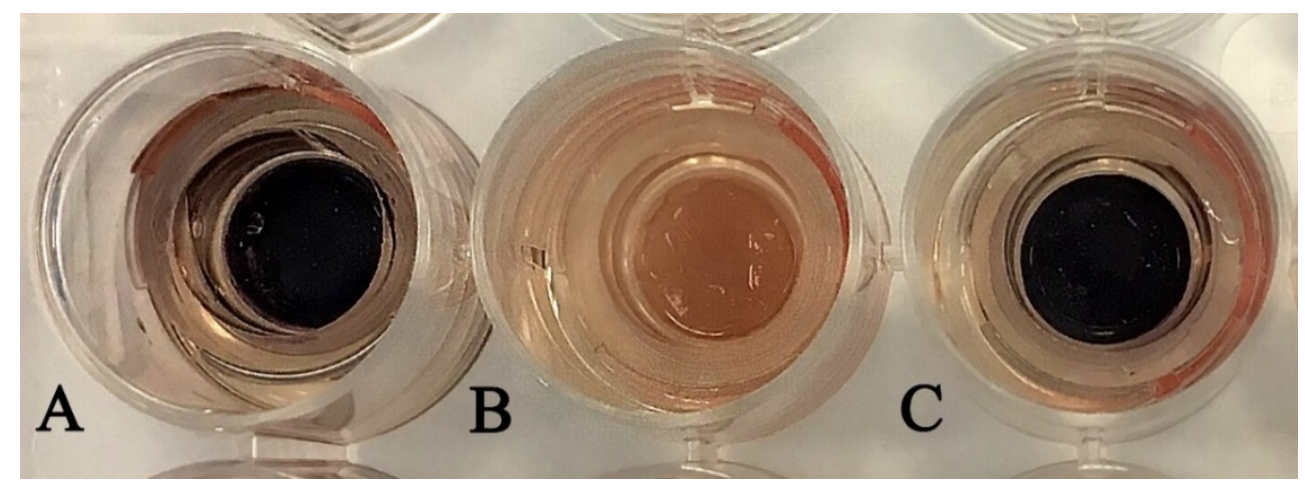

Figure 2. The view of the cell tissues during the in vitro skin irritation test after $18 \mathrm{~h}$ of incubation and cell viability determination by MTT. (A) — negative control, (B) - positive control, (C) - W/O/W emulsion.

In the skin phototoxicity test the EpiDerm ${ }^{\mathrm{TM}}$ skin inserts were exposed to 5 different concentrations of the water-diluted multiple $\mathrm{W} / \mathrm{O} / \mathrm{W}$ emulsions loaded with the extracts of Rosmarinus officinalis L., Avena sativa L. and Linum usitatissimum L in order to determine the threshold of photosensitivity. The parallel experiment with known phototoxic and cytotoxic compound chlorpromazine was performed as a positive control to prove the efficiency of the selected method [42]. It is already known that $0.005 \%$ and higher concentrations of chlorpromazine have phototoxic effect. $0.05 \%$ and higher concentrations of chlorpromazine results in the cytotoxicity when applied on the skin $[43,44]$. Nobile et al. have determined that $R$. officinalis and C. paradise extracts had photo-protective properties and could prevent the negative reactions caused by the UV rays when used topically on the skin [45]. The results of our study correspond with the data presented by other researchers. We found that the cell viability of the tissues affected with test sample (the $\mathrm{W} / \mathrm{O} / \mathrm{W}$ emulsion which contains herbal extracts of rosemary, oats and flaxseed) varied between 95.77 and $105.28 \%$. The concentration of the $\mathrm{W} / \mathrm{O} / \mathrm{W}$ emulsion had no significant impact on the cell viability as well [Figure 3]. No difference in the cell viability was observed between the test samples and negative control $(p<0.05)$. As expected, the positive control (chlorpromazine) decreased the cell viability by $59.24-68.67 \%$ at a concentration range of $0.005-0.01 \%$ when exposed to UV ( $p<0.05$ vs. negative control). At $0.05 \%$ and higher concentrations of chlorpromazine decreased the cell viability of the EpiDerm tissues by more than $90 \%$ not depending on the UV exposure. Thus, our results showed that the tested multiple $\mathrm{W} / \mathrm{O} / \mathrm{W}$ emulsion had neither phototoxic nor cytotoxic effects.

A lot of studies have evaluated and determined the antioxidant and anti-inflammatory effect of rosemary and its constituents $[46,47]$. The oatmeal extract containing $\beta$-glucans and active ingredients of the flaxseed extract are mentioned in the various scientific sources as natural ingredients with the potential to suppress inflammation as well $[48,49]$. Therefore, during the determination of the early inflammation in vitro the results showed that the amount of released IL- $1 \alpha$ into the media by the tissues with the $\mathrm{W} / \mathrm{O} / \mathrm{W}$ emulsion did not differ significantly from the negative control and untreated tissues, the IL- $1 \alpha$ concentrations were below $85 \mathrm{pg} / \mathrm{mL}$ (Figure 4). It was concluded that the application of the multiple emulsion with botanical extracts did not cause any inflammation in human keratinocytes. 


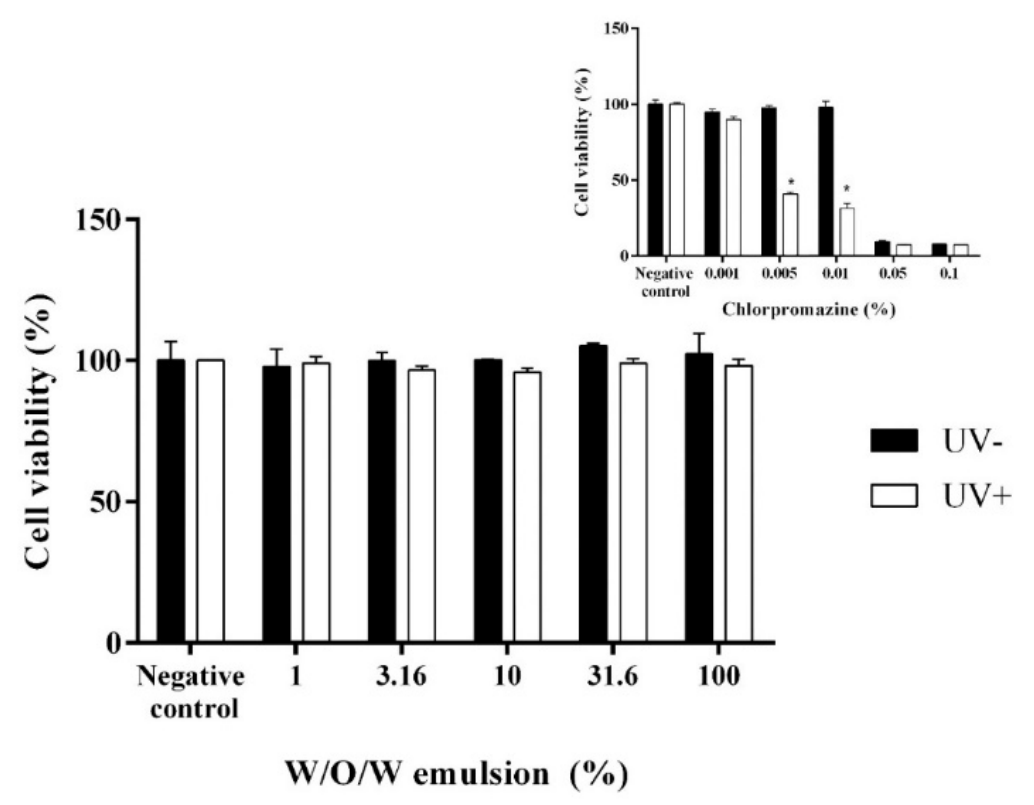

Figure 3. The influence of $\mathrm{W} / \mathrm{O} / \mathrm{W}$ emulsion and chlorpromazine on the cell viability during in vitro phototoxicity test. $\mathrm{N}=4 * p<0.05$ vs. UV-.

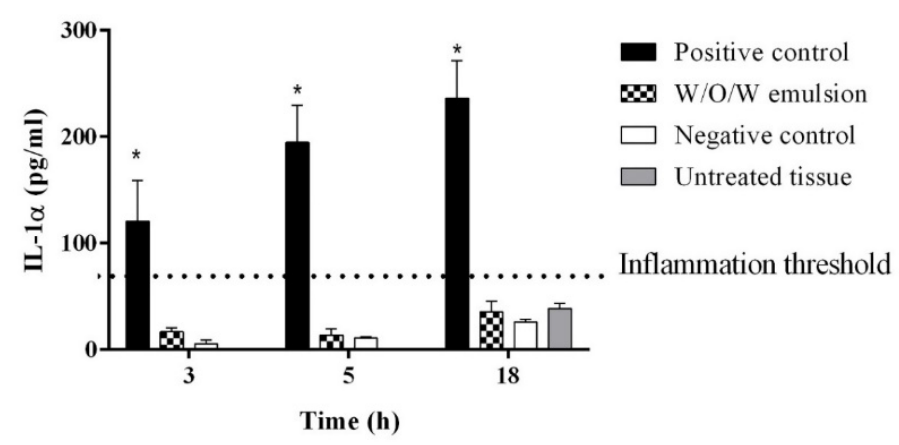

Figure 4. The influence of $\mathrm{W} / \mathrm{O} / \mathrm{W}$ emulsion on the inflammation marker IL-1 $\alpha$ release in vitro. $\mathrm{N}=4 * p<0.05$ vs. negative control, $\mathrm{W} / \mathrm{O} / \mathrm{W}$ emulsion and untreated tissue.

Recently, the research on botanical extracts and their active ingredients in food and cosmetic industry opened-up a pathway for the new applications of these bioactives, thus demanding a check to determine the frequency of allergic reactions [20,21]. In order to avoid the allergic reactions of the $\mathrm{W} / \mathrm{O} / \mathrm{W}$ emulsion which was formed using rosemary, flaxseed and oat extracts, the safety of the product was evaluated not only by the in vitro study of the 3D reconstructed human epidermis model, but also by the human skin patch testing. The total of 18 healthy volunteers have participated in the study. The results were evaluated after $48,72,96 \mathrm{~h}$ and 7 days after the $\mathrm{W} / \mathrm{O} / \mathrm{W}$ emulsion application using the Finn chambers. Despite that several studies have demonstrated that $0.1 \%$ rosemary leaf extract applied topically could cause skin erythema, our data contradicted with their results $[50,51]$. Moreover, Monice et al. stated that it is safe to use rosemary leaf extract up to the $10 \mathrm{~mL} / \mathrm{kg}$ and the pretreatment with 10 to $1000 \mu \mathrm{g} / \mathrm{cm}^{2}$ of the rosemary extract could significantly reduce ear edema caused by $25 \mathrm{ng} / \mathrm{cm}^{2}$ of 12-tetradecanoylphorbol-13-acetate in mice [52]. All the participants of the current study had negative reaction according to the International Contact Dermatitis Research Group criteria. Even if there are some contradictions related to the herbal extract (such as rosemary and oat)-induced allergic reactions, our results obtained by a patch test complies with the data obtained by the $3 \mathrm{D}$ reconstructed human epidermis in vitro, verifying that the innovative $\mathrm{W} / \mathrm{O} / \mathrm{W}$ emulsion does not cause any skin irritation in vivo. 


\section{Conclusions}

Due to the diverse phytochemical composition of botanical extracts which are used as the functional or active ingredients in topically applied formulations it is pertinent to evaluate their safety to avoid the possible allergic/irritation reactions. The 3D reconstructed human epidermis models can be used as an alternative to animal testing that allows to predict the skin reaction and correlates with the results of in vivo testing. According to the obtained data, it could be concluded that the object of this study-the innovative multiple $\mathrm{W} / \mathrm{O} / \mathrm{W}$ type emulsion formed and preserved directly using the plant extracts complies with the safety requirements and may be used as an innovative base in the development of the final high-quality cosmetic or pharmaceutical products. In the future, further experiments are foreseen to evaluate the possible use of rosemary and other extracts involved in the study as natural preservatives as well as to evaluate the efficacy of these complex emulsions on the human skin in vivo.

Author Contributions: Conceptualization, U.Z. and J.B. (Juste Baranauskaite); methodology, U.Z. and D.M.K.; software, U.Z.; validation, J.B. (Jurga Bernatoniene); formal analysis U.Z.; investigation, U.Z. and J.B. (Juste Baranauskaite); resources, J.B (Jurga Bernatoniene) and U.Z.; data curation, U.Z.; writing-original draft preparation, U.Z. and D.M.K.; writing—review \& editing, U.Z.; visualization, U.Z. and D.M.K.; supervision, J.B. (Jurga Bernatoniene); project administration, J.B. (Jurga Bernatoniene); funding acquisition J.B. (Jurga Bernatoniene). All authors have read and agreed to the published version of the manuscript.

Funding: This research received no external funding.

Institutional Review Board Statement: The study was conducted according to the guidelines of the Declaration of Helsinki, and approved by the Institutional Ethics Committee of Lithuanian University of Health Sciences (protocol code 102 and date of approval 15/04/2018).

Informed Consent Statement: Informed consent was obtained from all subjects involved in the study.

Data Availability Statement: Not applicable.

Acknowledgments: The authors wish to thank Pharmaceutical and Health technology Open access center and Science Foundation of Lithuanian University of Health Sciences, general and aesthetic dermatology clinic "Clinic In" and Rūta Gancevičienè for the support of this study and shared knowledge.

Conflicts of Interest: The authors declare no conflict of interest.

\section{References}

1. Baumann, L.S. Less-known botanical cosmeceuticals. Dermatol. Ther. 2007, 20, 330-342. [CrossRef]

2. Akhtar, M.; Murray, B.S.; Afeisume, E.I.; Khew, S.H. Encapsulation of flavonoid in multiple emulsion using spinning disc reactor technology. Food Hydrocoll. 2014, 34, 62-67. [CrossRef]

3. Mahmood, T.; Akhtar, N. Stability of a cosmetic multiple emulsion loaded with green tea extract. Sci. World J. $2013,2013,1-7$. [CrossRef] [PubMed]

4. Pal, R. Rheology of simple and multiple emulsions. Curr. Opin. Colloid Interface Sci. 2011, 16, 41-60. [CrossRef]

5. Cizauskaite, U.; Marksiene, R.; Viliene, V.; Gruzauskas, R.; Bernatoniene, J. New strategy of multiple emulsion formation based on the interactions between polymeric emulsifier and natural ingredients. Colloids Surf. A Physicochem. Eng. Asp. 2017, 515, 22-33. [CrossRef]

6. Sun, C.; Gunasekaran, S. Effects of protein concentration and oil-phase volume fraction on the stability and rheology of menhaden oil-in-water emulsions stabilized by whey protein isolate with xanthan gum. Food Hydrocoll. 2009, 23, 165-174. [CrossRef]

7. Pootongkam, S.; Nedorost, S. Oat and wheat as contact allergens in personal care products. Dermatitis 2013, 24, $291-295$. [CrossRef] [PubMed]

8. Astier, C.; Benchad Yel, A.; Moneret-Vautrin, D.A.; Bihain, B.E.; Kanny, G. Anaphylaxis to argan oil. Allergy 2010, 65, 662-663. [CrossRef] [PubMed]

9. Ortiz, K.J.; Yiannias, J.A. Contact dermatitis to cosmetics, fragrances, and botanicals. Dermatol. Ther. 2004, 17, 264-271. [CrossRef]

10. Kiken, D.A.; Cohen, D.E. Contact dermatitis to botanical extracts. Am. J. Contact Dermat. Off. J. Am. Contact Dermat. Soc. 2002, 13, 148-152. 
11. Yamakawa, Y.; Ohsuna, H.; Aihara, M.; Tsubaki, K.; Ikezawa, Z. Contact urticaria from rice. Contact Dermat. 2001, 44, 91-93. [CrossRef] [PubMed]

12. Amaro, C.; Goossens, A. Immunological occupational contact urticaria and contact dermatitis from proteins: A review. Contact Dermat. 2008, 58, 67-75. [CrossRef]

13. EU, Regulation (EC) No 1223/2009 of the European Parliament and of the Council of 30 November 2009 on Cosmetic Products. Available online: http:/ / eur-lex.europa.eu/legal-content/EN/ALL/?uri=CELEX:32009R1223 (accessed on 2 August 2017).

14. Draize, J.H.; Woodard, G.; Calvery, H.O. Methods for the study of irritation and toxicity of substances applied topically to the skin and mucous membranes. J. Pharmacol. Exp. Ther. 1944, 82, 377-390.

15. El Ghalbzouri, A.; Siamari, R.; Willemze, R.; Ponec, M. Leiden reconstructed human epidermal model as a tool for the evaluation of the skin corrosion and irritation potential according to the ECVAM guidelines. Toxicol. Vitro 2008, 22, 1311-1320. [CrossRef]

16. Basketter, D.A.; Chamberlain, M.; Griffiths, H.A.; Rowson, M.; Whittle, E.; York, M. The classification of skin irritants by human patch test. Food Chem. Toxicol. 1997, 35, 845-852. [CrossRef]

17. Robinson, M.K.; McFadden, J.P.; Basketter, D.A. Validity and ethics of the human 4-h patch test as an alternative method to assess acute skin irritation potential. Contact Dermat. 2001, 45, 1-12. [CrossRef] [PubMed]

18. McKim, J.M.; Keller, D.J.; Gorski, J.R. An in vitro method for detecting chemical sensitization using human reconstructed skin models and its applicability to cosmetic, pharmaceutical, and medical device safety testing. Cutan. Ocular Toxicol. 2012, 31, 292-305. [CrossRef]

19. Schlotmann, K.; Kaeten, M.; Black, A.F.; Damour, O.; Waldmann-Laue, M.; Förster, T. Cosmetic efficacy claims in vitro using a three-dimensional human skin model. Int. J. Cosmet. Sci. 2001, 23, 309-318. [CrossRef]

20. Nohynek, G.J.; Antignac, E.; Re, T.; Toutain, H. Safety assessment of personal care products/cosmetics and their ingredients. Toxicol. Appl. Pharmacol. 2010, 243, 239-259. [CrossRef]

21. Krausz, A.; Gunn, H.; Friedman, A. The basic science of natural ingredients. J. Drugs Dermatol. 2014, 13, 937-945.

22. Jirova, D.; Basketter, D.; Liebsch, M.; Bendova, H.; Kejlova, K.; Marriott, M.; Kandarova, H. Comparison of human skin irritation patch test data with in vitro skin irritation assays and animal data. Contact Dermat. 2010, 62, 109-116. [CrossRef]

23. Spielmann, H.; Liebsch, M.; Pape, W.J.; Balls, M.; Dupuis, J.; Klecak, G.; Lovell, W.W.; Maurer, T.; De Silva, O.; Steiling, W. EEC/COLIPA in vitro photoirritancy program: Results of the first stage of validation. Curr. Probl. Dermatol. 1995, $23,256-264$.

24. Kanto, H.; Washizaki, K.; Ito, M.; Matsunaga, K.; Akamatsu, H.; Kawai, K.; Katoh, N.; Natsuaki, M.; Yoshimura, I.; Kojima, H.; et al. Optimal patch application time in the evaluation of skin irritation. J. Dermatol. 2013, 40, 363-369. [CrossRef]

25. Bernatoniene, J.; Cizauskaite, U.; Ivanauskas, L.; Jakstas, V.; Kalveniene, Z.; Kopustinskiene, D.M. Novel approaches to optimize extraction processes of ursolic, oleanolic and rosmarinic acids from Rosmarinus officinalis leaves. Ind. Crop. Prod. 2016, 84, 72-79. [CrossRef]

26. Cizauskaite, U.; Bernatoniene, J. Innovative Natural Ingredients-Based Multiple Emulsions: The Effect on Human Skin Moisture, Sebum Content, Pore Size and Pigmentation. Molecules 2018, 23, 1428. [CrossRef]

27. Cizauskaite, U.; Ivanauskas, L.; Jakštas, V.; Marksiene, R.; Jonaitiene, L.; Bernatoniene, J. Rosmarinus officinalis L. extract and some of its active ingredients as potential emulsion stabilizers: A new approach to the formation of multiple (W/O/W) emulsion. Pharm. Dev. Technol. 2016, 21, 716-724. [PubMed]

28. Cizauskaite, U.; Marksa, M.; Bernatoniene, J. The optimization of technological processes, stability and microbiological evaluation of innovative natural ingredients-based multiple emulsion. Pharm. Dev. Technol. 2017, 23, 636-645. [CrossRef] [PubMed]

29. CIOMS. International Ethical Guidelines for Biomedical Research Involving Human Subjects; Council for International Organizations of Medical Sciences (CIOMS): Geneva, Switzerland, 2002.

30. Fonacier, L. A Practical Guide to Patch Testing. J. Allergy Clin. Immunol. Pract. 2015, 3, 669-675. [CrossRef]

31. Fonacier, L.; Bernstein, D.I.; Pacheco, K.; Holness, D.L.; Blessing-Moore, J.; Khan, D.; Lang, D.; Nicklas, R.; Oppenheimer, J.; Portnoy, J.; et al. Contact dermatitis: A practice parameter-update 2015. J. Allergy Clin. Immunol. Pract. 2015, 3, S1-S39. [CrossRef]

32. Anand, S.; Sati, N. Artificial preservatives and their harmful effects: Looking toward nature for safer alternatives. Int. J. Pharm. Sci. Res. 2013, 4, 2496.

33. Varvaresou, A.; Papageorgiou, S.; Tsirivas, E.; Protopapa, E.; Kintziou, H.; Kefala, V.; Demetzos, C. Self-preserving cosmetics. Int. J. Cosmet. Sci. 2009, 31, 163-175. [CrossRef] [PubMed]

34. Choulitoudi, E.; Ganiari, S.; Tsironi, T.; Ntzimani, A.; Tsimogiannis, D.; Taoukis, P.; Oreopoulou, V. Edible coating enriched with rosemary extracts to enhance oxidative and microbial stability of smoked eel fillets. Food Packag. Shelf Life 2017, 12, 107-113. [CrossRef]

35. Kaczmarczyk, D.; Strub, D.; Polowy, A.; Lochyński, S. Selected essential oils in cosmetic emulsions: Process oriented stability studies and antimicrobial activity. Nat. Volatiles Essent. Oils 2015, 2, $27-39$.

36. Ozogul, Y.; Yuvka, İ.; Ucar, Y.; Durmus, M.; Kösker, A.R.; Öz, M.; Ozogul, F. Evaluation of effects of nanoemulsion based on herb essential oils (rosemary, laurel, thyme and sage) on sensory, chemical and microbiological quality of rainbow trout (Oncorhynchus mykiss) fillets during ice storage. LWT Food Sci. Technol. 2017, 75, 677-684. [CrossRef]

37. Moreno, S.; Scheyer, T.; Romano, C.S.; Vojnov, A.A. Antioxidant and antimicrobial activities of rosemary extracts linked to their polyphenol composition. Free Radic. Res. 2006, 40, 223-231. [CrossRef] [PubMed] 
38. Adham, A.N.; Hui-Duan, L. Comparative extraction methods, phytochemical constituents, fluorescence analysis and HPLC validation of rosmarinic acid content in Mentha piperita, Mentha longifolia and Osimum basilicum. J. Pharmacogn. Phytochem. 2015, 3, 130-139.

39. Belsito, D.V.; Hill, R.A.; Klaassen, C.D.; Liebler, D.C.; Marks, J.G., Jr.; Shank, R.C.; Slaga, T.J.; Snyder, P.W. Safety Assessment of Rosmarinus officinalis (Rosemary)-Derived Ingredients as Used in Cosmetics. 2013. Available online: http:/ / www.cir-safety.org/ sites/default/files/rosmarinus_0.pdf (accessed on 15 May 2021).

40. Lachenmeier, D.W. Safety evaluation of topical applications of ethanol on the skin and inside the oral cavity. J. Occup. Med. Toxicol. 2008, 3, 26. [CrossRef]

41. Cartner, T.; Brand, N.; Tian, K.; Saud, A.; Carr, T.; Stapleton, P.; Lane, M.; Rawlings, A. Effect of different alcohols on stratum corneum kallikrein 5 and phospholipase A2 together with epidermal keratinocytes and skin irritation. Int. J. Cosmet. Sci. 2017, 39, 188-196. [CrossRef] [PubMed]

42. Monteiro, A.F.; Rato, M.; Martins, C. Drug-induced photosensitivity: Photoallergic and phototoxic reactions. Clin. Dermatol. 2016, 34, 571-581. [CrossRef] [PubMed]

43. Broeders, J.J.; Blaauboer, B.J.; Hermens, J.L. In vitro biokinetics of chlorpromazine and the influence of different dose metrics on effect concentrations for cytotoxicity in Balb/c 3T3, Caco-2 and HepaRG cell cultures. Toxicol. Vitro 2013, 27, 1057-1064. [CrossRef] [PubMed]

44. Gill, L.; Lim, H.W. Drug-induced photosensitivity. In Cutaneous Drug Eruptions; Springer: Berlin/Heidelberg, Germany, 2015; pp. 107-121.

45. Nobile, V.; Michelotti, A.; Cestone, E.; Caturla, N.; Castillo, J.; Benavente-García, O.; Pérez-Sánchez, A.; Micol, V. Skin photoprotective and antiageing effects of a combination of rosemary (Rosmarinus officinalis) and grapefruit (Citrus paradisi) polyphenols. Food Nutr. Res. 2016, 60, 31871. [CrossRef] [PubMed]

46. Chiu, A.; Kimball, A. Topical vitamins, minerals and botanical ingredients as modulators of environmental and chronological skin damage. Br. J. Dermatol. 2003, 149, 681-691. [CrossRef]

47. Peng, C.-H.; Su, J.-D.; Chyau, C.-C.; Sung, T.-Y.; Ho, S.-S.; Peng, C.-C.; Peng, R.Y. Supercritical fluid extracts of rosemary leaves exhibit potent anti-inflammation and anti-tumor effects. Biosci. Biotechnol. Biochem. 2007, 71, 2223-2232. [CrossRef] [PubMed]

48. Rabetafika, H.N.; Van Remoortel, V.; Danthine, S.; Paquot, M.; Blecker, C. Flaxseed proteins: Food uses and health benefits. Int. J. Food Sci. Technol. 2011, 46, 221-228. [CrossRef]

49. Smiderle, F.R.; Olsen, L.M.; Carbonero, E.R.; Baggio, C.H.; Freitas, C.S.; Marcon, R.; Santos, A.R.; Gorin, P.A.; Iacomini, M. Antiinflammatory and analgesic properties in a rodent model of a $(1 \rightarrow 3),(1 \rightarrow 6)$-linked $\beta$-glucan isolated from Pleurotus pulmonarius. Eur. J. Pharmacol. 2008, 597, 86-91. [CrossRef]

50. Boussault, P.; Léauté-Labrèze, C.; Saubusse, E.; Maurice-Tison, S.; Perromat, M.; Roul, S.; Sarrat, A.; Taïeb, A.; Boralevi, F. Oat sensitization in children with atopic dermatitis: Prevalence, risks and associated factors. Allergy 2007, 62, 1251-1256. [CrossRef]

51. Rokaitè, R.; Labanauskas, L.; Vaidelienè, L. Role of the skin patch test in diagnosing food allergy in children with atopic dermatitis. Medicina 2004, 40, 1081-1087.

52. Fiume, M.M.; Bergfeld, W.F.; Belsito, D.V.; Hill, R.A.; Klaassen, C.D.; Liebler, D.C.; Marks, J.G., Jr.; Shank, R.C.; Slaga, T.J.; Snyder, P.W. Safety Assessment of Rosmarinus officinalis (Rosemary)-Derived Ingredients as Used in Cosmetics. Int. J. Toxicol. 2018, 37, 12S-50S. [CrossRef] 